KOVID-19 - AKTUELNO STANJE MENTALNOG ZDRAVLJA SA OSVRTOM NA ZDRAVSTVENE RADNIKE

PREGLEDNI RAD

REVIEW ARTICLE

\title{
COVID-19 - CURRENT STATE OF MENTAL HEALTH WITH A REFERENCE TO HEALTH WORKERS
}

\author{
Milan Latas ${ }^{1,2}$, Maja Pantović Stefanović ${ }^{1,2}$, Bojana Đukić ${ }^{2}$ \\ 1 Klinika za psihijatriju, Univerzitetski klinički centar Srbije, \\ Beograd, Srbija \\ 1 Clinic for Psychiatry, University Clinical Center of Serbia, Belgrade, \\ Serbia \\ 2 Medicinski fakultet, Univerzitet u Beogradu, Beograd, Srbija \\ 2 Faculty of Medicine, University of Belgrade, Belgrade, Serbia
}

\section{SAŽETAK}

Uvod: Pandemija KOVID-19 oboljenja je donela puno problema i izazova medicinskoj struci, uključujući tu i oblast psihijatrije. Ovi problemi i izazovi uključuju pojavu de novo poremećaja u populaciji, pogoršanje stanja kod ranije dijagnostikovanih pacijenata, ali i pojavu problema u mentalnom funkcionisanju zdravstvenih radnika, koji su bili uključeni u lečenje pacijenata obolelih od KOVID-19 infekcije. 0 svim ovim problemima i izazovima svedoče brojni međunarodni radovi, ali i dobar broj istraživanja i saopštenja koje su publikovali srpski istraživači i stručnjaci u domaćim i stranim publikacijama.

Cilj: Cilj rada jeste da se istraže i prezentuju istraživanja rađena u Republici Srbiji u vezi sa KOVID-19 infekcijom i njenim uticajem na mentalno zdravlje.

Metode: $U$ ovom radu su prikazani rezultati domaćih istraživanja i stručna mišljenja u vezi sa KOVID-19 infekcijom i njenim uticajem na mentalno zdravlje. Kao osnova pripreme rada, poslužile su publikacije domaćih autora, koje su objavljene mahom na međunarodnom nivou. U tim publikacijama ima rezultata originalnih istraživanja, ali i stručnih razmatranja u vezi sa uticajem KOVID-19 infekcije na mentalno zdravlje.

Rezultati: Dosadašnja istraživanja i obimna klinička praksa na teritoriji Republike Srbije ukazuju na postojanje učestalih i intenzivnih problema u vezi sa mentalnim zdravljem, kako opšte, tako i specifičnih populacija, kao što su zdravstveni radnici i pacijenti oboleli od psihijatrijskih poremećaja, a koji su posledica pandemije KOVID-19 oboljenja.

Zaključak: Na osnovu prikazanih rezultata, proizilazi zaključak da je potrebno da se na teritoriji cele Republike Srbije otvori veći broj specijalizovanih ustanova, koje će se baviti ovom problematikom i gde bi pacijenti mogli da pronađu podršku i pomoć za svoje probleme.

Ključne reči: pandemija, KOVID-19, mentalno zdravlje, populacija

\begin{abstract}
Introduction: The COVID-19 pandemic has brought many problems and challenges to the medical profession, including psychiatry. These include the emergence of de novo disorders in the population, the worsening of the condition in previously diagnosed patients, but also problems in the mental functioning of health professionals, who were involved in the treatment of COVID-19 patients. Numerous international papers address these problems and challenges, as is the case with a large number of studies and papers published by Serbian researchers and experts in Serbian and international publications.
\end{abstract}

Objective: The objective of the paper is to present research conducted in the Republic of Serbia related to the COVID-19 infection and its impact on mental health.

Methods: This paper presents the results of Serbian research as well as expert opinions related to the COVID-19 infection and its impact on mental health. The basis for the preparation of this paper were publications of Serbian authors published mostly in international journals. These publications present the results of original studies, but also expert considerations related to the impact of the COVID-19 infection on mental health.

Results: Previous research and extensive clinical practice in the Republic of Serbia show the existence of frequent and intensive problems related to mental health, resulting from the COVID-19 pandemic, present in both the general population and in specific populations, such as health workers and patients suffering from psychiatric disorders.

Conclusion: Based on the presented results, the conclusion is that, in order to deal with this issue, a number of specialized institutions should be opened in the territory of the entire Republic of Serbia, where patients could find support and help for their problems.

Key words: pandemic, COVID-19, mental health, population 


\section{UVOD}

Pandemija KOVID-19 oboljenja je donela puno problema i izazova medicinskoj struci, uključujući tu i oblast psihijatrije. Oni uključuju pojavu de novo poremećaja u populaciji, pogoršanje stanja kod ranije dijagnostikovanih pacijenata, ali i pojavu problema u mentalnom funkcionisanju zdravstvenih radnika koji su bili uključeni u lečenje pacijenata obolelih od KOVID-19 infekcije. O svim ovim problemima i izazovima svedoče radovi publikovani u međunarodnim časopisima, ali i istraživanja i saopštenja koja su publikovali srpski istraživači i stručnjaci u domaćim i međunarodnim publikacijama.

$\mathrm{U}$ ovom radu će biti prikazani rezultati domaćih istraživanja i stručna mišljenja u vezi sa KOVID-19 infekcijom i njenim uticajem na mentalno zdravlje. Kao osnova pripreme rada, poslužile su publikacije domaćih autora, koje su objavljene mahom na međunarodnom nivou. $U$ tim publikacijama ima rezultata originalnih istraživanja, ali i stručnih razmatranja u vezi sa uticajem KOVID-19 infekcije na mentalno zdravlje.

\section{MENTALNO ZDRAVLJE NACIJE U PANDEMIJI}

U poslednjih godinu i po dana, psihijatri i ostali stručnjaci koji su se bavili mentalnim zdravljem, uočili su brojne probleme $u$ mentalnom funkcionisanju, koji su se pojavili u prvoj fazi pandemije, uključujući tu i vreme karantina i zatvaranja. U svom radu, Vujičić i saradnici [1] su ispitivali uticaj pandemije KOVID-19 oboIjenja na mentalno zdravlje opšte populacije u Srbiji, uz istraživanje faktora koji su dovodili do pogoršanja mentalnog zdravlja u periodu vanredne situacije. Studija je sprovedena putem online upitnika (metodologija koju je bilo moguće primeniti u tom periodu) kojim je, na uzorku opšte populacije, ispitivan stepen intenziteta depresije, anksioznosti i stresa. U zaključku su autori izneli da su stres, anksioznost i depresija, mereni Skalom depresivnosti, anksioznosti i stresa-21 (engl. - Depression, Anxiety and Stress Scale - 21 Items - DASS21), bili povišeni za vreme karantina i zatvaranja, a da je osećaj bespomoćnosti bio najviše povezan sa navedenom problematikom. Sa druge strane, dobro zdravlje i viši socioekonomski status su bili povezani sa manjim intenzitetom simptoma anksioznosti, depresije i stresa.

Autori iz Novog Sada, Sadiković i saradnici [2], pratili su emocionalno stanje opšte populacije, u dužem vremenskom periodu. Na uzorku od 1.526 učesnika studije iz opšte populacije, autori su zaključili da je problem emocionalnog stanja vezan za pandemiju KOVID-19 oboljenja varirao tokom vremena, a da je vremenom najviše došlo do umanjenja simptoma brige, straha i dosade, što je bila posledica uspešne adaptacije na novonastale okolnosti.

\section{INTRODUCTION}

The COVID-19 pandemic has brought many problems and challenges to the medical profession, including psychiatry. These include the emergence of de novo disorders in the population, the worsening of the condition in previously diagnosed patients, but also problems in the mental functioning of health professionals, who were involved in the treatment of COVID-19 patients. Numerous international papers address these problems and challenges, as is the case with a number of studies and papers published by Serbian researchers and experts in Serbian and international publications.

The results of Serbian research as well as expert opinions related to the COVID-19 infection and its impact on mental health will be presented in this paper. The basis for the preparation of this paper were publications of Serbian authors published mostly in international journals. These publications present the results of original studies, but also expert considerations related to the impact of the COVID-19 infection on mental health.

\section{MENTAL HEALTH STATUS OF THE NATION IN THE PANDEMIC}

In the previous year and a half, psychiatrists and other experts involved in mental health have noted numerous problems in mental functioning that emerged in the first phase of the pandemic, which included the period of quarantine and lockdown. In their paper, Vujičić et al. [1] analyzed the effect of the COVID-19 pandemic on the mental health of the general population in Serbia, at the same time researching the factors that led to the worsening of mental health in the period of the state of emergency. The study was carried out via an online questionnaire (the methodology that was feasible in the period in question) which tested, on a sample of the general population, the level of intensity of depression, anxiety and stress. In their conclusion, the authors stated that stress, anxiety and depression, measured with the Depression, Anxiety and Stress Scale - 21 Items (DASS-21), were elevated during quarantine and lockdown, while the feeling of helplessness was mostly connected to the above stated problems. On the other hand, good health and a higher socioeconomic status were connected to a lesser intensity of the symptoms of anxiety, depression, and stress.

Authors from Novi Sad, Sadiković et al. [2], followed the emotional state of the general population over a longer period of time. On a sample of 1,526 participants in the study, from the general population, the authors concluded that problems related to the emotional state in connection with the COVID-19 pandemic varied over time, and that, with time, the symptoms of worry, fear, 


\section{STANJE ZDRAVSTVENIH RADNIKA U PANDEMIJI}

Tokom pandemije, zdravstveni radnici, uključujući lekare, medicinske sestre i drugo zdravstveno osoblje, susreli su se sa nizom različitih problema, koji pre toga nisu postojali - susret sa nepoznatom bolešću, nova organizacija službe, briga za sebe, pacijente i porodicu, intenzivan rad i preopterećenost. Lični utisci autora, prilikom kontakta sa medicinskim radnicima koji su radili u specijalnim kovid bolnicama, bili su da su ovi zdravstveni radnici pokazivali intenzivan umor, iscrpljenost, zabrinutost, uz žalbe na loš san i brigu koja ih opseda. Što se tiče pojave psihičkih simptoma, najprominentnija je bila nesanica, a potom anksioznost, briga i strah, s jedne strane, i disforija i razdražljivost, s druge strane. Ipak utisak je da je većina zdravstvenih radnika pokazivala rezilijentnost odnosno uspešnost u ličnom i profesionalnom funkcionisanju, uprkos novonastalim poteškoćama i izazovima.

Istraživanje sprovedeno u Kragujevcu [3] upravo ukazuje da su faktori rizika za pojavu stresa kod medicinskog osoblja tokom pandemije KOVID-19 oboljenja bili mlađi uzrast i porodična opterećenost pojavom mentalnih poremećaja, a da je rezilijentnost bila zaštitni faktor u pojavi simptoma stresa. U prilog tezi da su medicinski radnici tokom pandemije pokazali rezilijentnost idu i rezultati istraživanja dr Marije Lazarević, iz Loznice [4]. U ovom istraživanju se došlo do zaključka da su medicinski radnici emocionalno stabilni i da pandemija nije izazvala veću nesigurnost, čak ni u trenucima najvećeg porasta broja obolelih.

Istraživački tim iz Niša [5] je poredio mentalno stanje medicinskih radnika koji su radili u kovid sistemu i onih koji nisu radili u kovid sistemu. Rezultati ovog istraživanja pokazuju da su medicinski radnici u kovid sistemu imali veći intenzitet simptoma stresa, anksioznosti i depresije, u odnosu na kolege van kovid sistema, te je predloženo da se sprovedu adekvatne mere sa ciljem umanjenja intenziteta tih simptoma i boljeg mentalnog funkcionisanja. Slično istraživanje su sproveli Stojanov i saradnici [6]. Ova grupa autora je takođe ispitivala anksioznost i depresiju kod zdravstvenih radnika, ali i kvalitet života i obrasce spavanja u ispitivanom uzorku. Oni su u zaključku izneli da zdravstvenim radnicima problem predstavlja nesanica, koja je povezana sa simptomima anksioznosti i depresije, uz naznaku da je za pojedine ispitanike potrebna psihološka podrška.

\section{PANDEMIJA I SPECIFIČNE POPULACIJE}

Pored problema mentalnog zdravlja, koji su ispitivani na uzorcima opšte populacije, istraživanja psihičkog funkcionisanja su obuhvatala i specifične populacije kao što su deca, studenti, itd. Grupa autora iz Instituta za mentalno zdravlje u Beogradu je ukazala da deca predstavljaju posebno vulnerabilnu populaciju u and boredom decreased the most, which was the result of successful adaptation to new life circumstances.

\section{STATUS OF HEALTH WORKERS IN THE PAN- DEMIC}

During the pandemic, health workers, including doctors, nurses, and other medical staff, have met with a series of different problems, which did not exist before - encountering an unknown disease, adjusting to a different organization of work, worrying about one's own and the wellbeing of one's family, worrying about the wellbeing of the patients, working intensively, being overburdened. Upon meeting with medical staff working in covid hospitals, the personal impressions of the authors of the present study were that these health workers exhibited extreme fatigue, exhaustion, concern; they complained of not sleeping properly and of being haunted by worry. As to the development of symptoms, the most prominent symptom was insomnia, followed by anxiety, worry and fear, on the one hand, and dysphoria and irritability, on the other. However, the impression is that most health workers demonstrated resilience, i.e., success in functioning, both personally and professionally, despite the new difficulties and challenges.

In fact, a study carried out in Kragujevac [3] indicates that the risk factors for stress in medical staff during the COVID-19 pandemic were younger age and a genetic basis for the development of mental disorders, while resilience was a protective factor against stress-related symptoms. The results of a study carried out by Dr. Marija Lazarević, from Loznica, also speak in favor of the resilience of health workers during the pandemic [4]. In this study, the conclusion was that health workers were emotionally stable and that the pandemic did not cause major insecurity, even in times of the greatest rise of the number of COVID-19 cases.

A research team from Niš [5] compared the mental state of medical staff working in the covid system against the mental state of medical staff not working in the covid system. The results of this study show that the medical staff working in the covid system displayed a higher intensity in symptoms of stress, anxiety, and depression, as compared to their colleagues who were outside the covid system, which is why it was suggested that appropriate measures should be taken in order to alleviate the intensity of these symptoms and improve the mental functioning of health workers. A similar study was carried out by Stojanov et al. [6]. This group of authors analyzed anxiety and depression in health workers as well, but they also focused on the quality of life and sleeping patterns in the analyzed sample. In their conclusion they state that a problem for medical workers is insomnia, which is linked to symptoms of 
kriznim situacijama, a da se psihičke tegobe kod dece najčešće javljaju usled teškog razumevanja novih okolnosti, straha, odvojenosti od vršnjaka, izmena psihičkog stanja roditelja [7]. Pored toga, otežanom mentalnom funkcionisanju doprinose i sistemske promene u državi, kao što su zatvaranje vaspitnih i obrazovnih ustanova i smanjenje obima rada ustanova za pomoć i podršku deci i ugroženim porodicama. Ovo se posebno odnosi na decu sa već postojećim psihičkim smetnjama, neuro-razvojnim poteškoćama i decu iz ugroženih i manjinskih grupa, koje zahtevaju veću brigu i podršku sistema.

$\mathrm{S}$ jedne strane, studentska populacija često pokazuje rezilijentnost u stresogenim okolnostima, ali s druge strane, može da predstavlja i posebno vulnerabilnu grupu, koja zahteva specifičnu pažnju. Istraživanje autora iz Niša na uzorku akademske populacije je ukazalo na povišen intenzitet stresa, koji je bio povezan sa specifičnim varijablama, kao što su ženski pol i izbegavanje kao "koping" mehanizam (engl. coping mechanism) [8].

Pored navedenih specifičnih populacija, posebnu pažnju tokom pandemije KOVID-19 oboljenja zaslužuju i pacijenti oboleli od psihijatrijskih poremećaja. Prema najnovijem istraživanju sprovedenom na teritoriji cele Republike Srbije, na uzorku od 1.785 pacijenata sa već dijagnostikovanim psihijatrijskim poremećajem, a koji su bili pretežno iz grupe anksioznih i depresivnih poremećaja, utvrđeno je da većina njih (gotovo tri četvrtine) pokazuje znake povišene anksioznosti, koja je posledica raznih aspekata u vezi sa pandemijom, a merena je Skalom za procenu generalizovanog anksioznog poremećaja (engl. Generalized Anxiety Disorder Assessment - GAD-7) [9]. Sve ovo ukazuje na važnost sagledavanja promene mentalnog stanja pacijenata obolelih od psihijatrijskih poremećaja, koje je u vezi sa postojanjem pandemije KOVID-19 oboljenja.

\section{PUTEVI BORBE - TERAPIJA I ORGANIZACIJA SLUŽBE}

Novonastale okolnosti u okviru pandemije dovele su do promene $u$ organizaciji pomoći pacijentima obolelih od mentalnih poremećaja [10]. Ove promene su uključivale, ili je trebalo da uključe, posebnu procenu stanja mentalnog zdravlja ljudi u različitim subpopulacijama, pod uticajem izbijanja pandemije KOVID-19 oboljenja; identifikovanje osoba koje su pod visokim rizikom od poremećaja ponašanja (pokušaj samoubistva, pojava agresije i sl.); kao i pružanje odgovarajućih intervencija zaštite mentalnog zdravlja onima kojima je pomoć potrebna.

Primena specifične farmakoterapije kod osoba obolelih od mentalnih poremećaja tokom pandemije morala je da doživi izvesne modifikacije jer je bilo anxiety and depression, with an additional comment that individual subjects needed psychological support.

\section{THE PANDEMIC AND SPECIFIC POPULATION GROUPS}

In addition to mental health problems analyzed on samples of the general population, studies of mental functioning also included particular groups of the population such as children, college students, etc. A group of authors from the Institute of Mental Health in Belgrade indicated that children represent a particularly vulnerable population in times of crisis, and that mental problems in children most commonly occur due to difficulties in understanding the new circumstances, fear, separation from their peers, changes in the mental state of their parents [7]. Additionally, impaired mental functioning is also the result of systemic administrative changes, such as the closing down of preschools, schools and other educational institutions, as well as the limiting of the scope of work of institutions that help and support vulnerable children and families. This is especially true of children with preexisting mental disorders, children with neurodevelopmental difficulties, and children from vulnerable and minority groups, who require additional care and support from the system.

On the one hand, the population of college and university students often demonstrates resilience in stressogenic circumstances, however, on the other hand, it can represent an especially vulnerable group requiring particular attention. A study by authors from Niš, on a sample of a university population indicated increased intensity of stress, which was connected to specific variables, such as female gender and avoidance as a coping mechanism [8].

In addition to the abovementioned specific population groups, special attention during the COVID-19 pandemic should be given to patients suffering from psychiatric disorders. According to the newest research carried out on the territory of the Republic of Serbia on a sample of 1,785 patients with previously diagnosed psychiatric disorders (mostly anxiety and depressive disorders), it was established that most of the subjects (almost three quarters of them) displayed signs of increased anxiety resulting from different aspects related to the pandemic, as measured by the Generalized Anxiety Disorder Assessment (GAD-7) scale [9]. All of this indicates the importance of considering the change of the mental state of patients suffering from mental disorders in connection to the COVID-19 pandemic.

\section{MANAGEMENT STRATEGIES - TREATMENT AND HEALTH SERVICE ORGANIZATION}

The new circumstances of the pandemic have led to a change in the organization of care for patients suffering 
očekivano da će se neki od pacijenata obolelih od mentalnih poremećaja razboleti i od KOVID-19 infekcije. Posebna pažnja pri istovremenoj primeni lekova za lečenje KOVID-19 infekcije i psihofarmaka mora obavezno da uključi i međusobne interakcije psihofarmaka sa drugim medikamentima i medicinskim sredstvima na nivou CYP enzima (engl. Cytochrome P450 enzymes) [11].

Pored navedenog, primećeno je da osobe obolele od KOVID-19 infekcije u bolničkim uslovima vrlo često pokazuju znake i simptome psihomotorne agitacije i delirijuma. U praksi je najvažnije da se ove teškoće na vreme otkriju u začetku, kako bi se izbeglo usložnjavanje simptoma i sprečile brojne komplikacije i problemi. Najčešći uzroci ovih simptoma su hipoksija, hipertermija, hipoglikemija, hipovolemija, promena acidobazne ravnoteže, ali i postojanje ranijih oštećenja CNS-a. Da bi se olakšala terapija ovih pacijenata, Psihijatrijska sekcija Srpskog lekarskog društva je objavila terapijske smernice za lečenje psihomotorne agitacije u sklopu epidemije KOVID-19 oboljenja [12]. U njima je na didaktičan način opisana procedura lečenja pacijenata sa psihomotornom agitacijom i delirijumom, koja može da pomogne u rešavanju ovih problema.

\section{ZAKLJUČAK}

Kao što je već napomenuto, pandemija KOVID-19 oboljenja je dovela do mnogih promena na ličnom, porodičnom i socijalnom planu svakog pojedinca, ali i do mnogih promena u funkcionisanju zdravstvenog sistema. Brojni izazovi su uslovili otvaranje novih bolnica i službi koje su se specijalizovale za lečenje i podršku pacijentima obolelih od KOVID-19 infekcije. Tako je, razumevanjem uprave Univerzitetskog kliničkog centra Srbije (UKCS), u okviru Klinike za psihijatriju UKCS-a u Beogradu, formirana specijalizovana ambulanta za lečenje post-kovid psihijatrijskih poremećaja i problema. U okviru ambulante se leče pacijenti koji su imali i ranije psihijatrijske probleme i poremećaje, ali i pacijenti kod kojih je otkriveno postojanje de novo poremećaja.

Dosadašnja istraživanja i obimna klinička praksa na teritoriji Republike Srbije ukazuju na postojanje učestalih $\mathrm{i}$ intenzivnih problema u vezi sa mentalnim zdravljem, koji su posledica pandemije KOVID-19 oboljenja. Zbog toga je važno da na teritoriji cele Republike Srbije postoji veći broj specijalizovanih službi koje će se baviti ovom problematikom i gde bi pacijenti mogli da pronađu podršku i pomoć za svoje probleme.

Rad je referisan na nacionalnom simpozijum „KOVID-19 - šta smo naučili do sada?" koji je održan u Vrnjačkoj Banji, 16. oktobra 2021.

Sukob interesa: Nije prijavljen. from psychiatric disorders [10]. These changes included or were supposed to include the following: special assessment of the mental status of people belonging to different subpopulations, under the influence of the outbreak of the COVID-19 pandemic; the identification of persons who are at increased risk of displaying behavioral disturbances (suicide attempts, manifestation of aggression, etc.); as well as providing appropriate mental health care interventions for those in need of assistance.

The application of specific pharmacotherapy in individuals suffering from mental disorders needed to undergo certain modifications during the pandemic, as it was to be expected that some of the patients suffering from mental disorders would be infected with COVID-19. Special attention during the simultaneous application of COVID-19 therapy and psychopharmaceuticals must include the consideration of the interaction between psychopharmaceuticals and other medicaments and medicinal products, at the level of the Cytochrome P450 enzymes (CYP) [11].

In addition to what has already been stated, it has been noted that, in hospital settings, COVID-19 patients very often display signs and symptoms of psychomotor agitation and delirium. It is of the utmost importance to recognize these difficulties early on, at the very onset, in order to avoid further compounding of the symptoms and prevent numerous complications and problems. The most common causes of these symptoms are hypoxia, hyperthermia, hypoglycemia, hypovolemia, change in the acid-base balance, as well as preexisting damage to the CNS. In order to facilitate the treatment of these patients, the Psychiatry Section of the Serbian Medical Society has published therapeutic guidelines for treating psychomotor agitation in the COVID-19 pandemic [12]. In an instructive manner, these guidelines describe the procedure for treating patients with psychomotor agitation and delirium, which can be helpful in resolving these issues.

\section{CONCLUSION}

As previously mentioned, the COVID-19 pandemic has led to many problems in the spheres of personal, family, and social life, for every individual, but it has also led to many changes in the functioning of the healthcare system. Numerous challenges have necessitated the opening of new hospitals and services specialized in treating and supporting COVID-19 patients. Thus, thanks to the support of the University Clinical Center of Serbia (UCCS) management, a specialized outpatient facility for treating post-covid psychiatric disorders and problems was formed within the Clinic for Psychiatry of the UCCS in Belgrade. This is a facility 


\section{LITERATURA / REFERENCES}

1. Vujčić I, Safiye T, Milikić B, Popović E, Dubljanin D, Dubljanin E, et al. Coronavirus Disease 2019 (COVID-19) Epidemic and Mental Health Status in the General Adult Population of Serbia: A Cross-Sectional Study. Int J Environ Res Public Health. 2021 Feb 17;18(4):1957. doi: 10.3390/ijerph18041957.

2. Sadiković S, Branovački B, Oljača M, Mitrović D, Pajić D, Smederevac S. Daily Monitoring of Emotional Responses to the Coronavirus Pandemic in Serbia: A Citizen Science Approach. Front Psychol. 2020 Aug 19;11:2133. doi: 10.3389/ fpsyg.2020.02133.

3. Ignjatović Ristić D, Hinić D, Banković D, Kočović A, Ristićl, Rosić G, et al. Levels of stress and resilience related to the COVID-19 pandemic among academic medical staff in Serbia. Psychiatry Clin Neurosci. 2020 Nov;74(11):604-5. doi: 10.1111/pcn.13124.

4. Lazarević M. Anksioznost kod zdravstvenih radnika u vreme pandemije COVID-19. Medicinski časopis. 2020;54(1):14-7. doi: 10.5937/mckg54-27871.

5. Antonijevic J, Binic I, Zikic O, Manojlovic S, Tosic-Golubovic S, Popovic N. Mental health of medical personnel during the COVID-19 pandemic. Brain Behav. 2020 Dec;10(12):e01881. doi: 10.1002/brb3.1881.

6. Stojanov J, Malobabic M, Stanojevic G, Stevic M, Milosevic V, Stojanov A. Quality of sleep and health-related quality of life among health care professionals treating patients with coronavirus disease-19. Int J Soc Psychiatry. 2021 Mar;67(2):175-81. doi: 10.1177/0020764020942800.

7. Grujičić R, Bogdanović J, Stupar S, Maslak J, Pejović-Milovančević M. C0VID-19 pandemija - uticaj na decu i mlade. Psihijatrija danas. 2020;52(12):99-111. doi: 10.5937/PsihDan2001099G

8. Kostić J, Žikić 0 , Đorđević $V$, Krivokapić Ž. Perceived stress among university students in south-east Serbia during the COVID-19 outbreak. Ann Gen Psychiatry. 2021 Apr 7;20(1):25. doi: 10.1186/s12991-021-00346-2.

9. Đukić B, Lalović N, Latas M. Uticaj pandemije Kovid-19 na intenzitet anksioznosti kod pacijenata obolelih od mentalnih poremećaja. Rad u pripremi.

10. Stašević-Karličić l, Đorđević V, Stašević M, Subotić T, Filipović Z, Ignjatović-Ristić $D$, et al. Perspectives on mental health services during the COVID-19 epidemic in Serbia. Srpski arhiv za celokupno lekarstvo 2020;(148):379-82. doi: 10.2298/SARH200504028S.

11. Milosavljević M, Vuković 0 . Primena psihofarmaka u toku lečenja COVID-19. Psihijatrija danas. 2020;52(1-2):89-97. doi: 10.5937/PsihDan2001089M.

12. Opanković A, Latas M, Milovanović S. Psihomotorna agitacija terapijske smernice psihijatrijske sekcije Srpskog lekarskog društva u sklopu epidemije COVID 19 u Republici Srbiji. Engrami. 2021;43(1):70-81. doi: 10.5937/engrami42-33720. where patients with previous psychiatric problems and disorders are treated, but also patients who have been diagnosed with de novo mental disorders.

Previous research and extensive clinical practice in the Republic of Serbia show the existence of frequent and intensive problems related to mental health, resulting from the COVID-19 pandemic. This is why it is important that a number of specialized institutions should function in the territory of the entire Republic of Serbia, where patients could find support and help for their problems.

The paper was presented at the national symposium "COVID-19 - What have we learned so far?" Which was held in Vrnjačka Banja on 0ctober 16, 2021.

Conflict of interest: None declared. 